Vol. LXIV No $1 \quad 2014$

\title{
ZEOLITE - A NATURAL FILTER MATERIAL FOR LEAD POLLUTED WATER
}

\author{
CORINA IOANA NEAMŢU \\ Faculty of Engineering Materials and the Environment/Environmental Engineering Department, Technical \\ University of Cluj-Napoca, Romania, corineamtu@gmail.com \\ ELENA MARIA PIC $\breve{A}$ \\ Faculty of Engineering Materials and the Environment/Environmental Engineering Department, Technical \\ University of Cluj-Napoca, Romania, elena.pica@chem.utcluj.ro
}

TIBERIU RUSU

Faculty of Engineering Materials and the Environment/Environmental Engineering Department, Technical University of Cluj-Napoca, Romania, tiberiu.rusu@sim.utcluj.ro

\begin{abstract}
Reducing the concentration of lead ions in a wastewater using zeolite has proven to be a successful water treatement method, all over the world. Putting the two media (solid and liquid) in contact in static conditions had good results regarding the concentration of the filtered solution, the $\mathrm{pH}$ and the electric conductivity, depending on the values of certain parameters such as the amount of the zeolite, volume of the solution or interaction time. The present study highlights the zeolite ability to retain the lead ions from a solution, in dynamic interaction conditions between the two environments, in a short interaction time. The results confirmed the effectiveness of ion exchange water treatment method in the conditions set, emphasizing once again the properties of the filter material - the zeolite.
\end{abstract}

Keywords: zeolite, ion exchange, groundwater pollution

\section{Introduction}

In many countries where the main source of water is the groundwater, the concern for its quality deterioration due to heavy metal pollution has increased significantly in the last 50 years. This concern is mainly due to the increasing of anthropogenic activities as direct pollution sources, originating from industrial, mining and agriculture activities (Wang et al., 2005). Because of the uncontrolled discharge of the industrial and mining wastewater into the natural receptors (groundwater and the surface water), the heavy metals concentration increased alarmingly (Yi et al., 2011). Lead is one of the heavy metals that are often found in wastewaters. It is a harmful element for both soil and water, and for plants and human health as well (Singh et al., 2010; Wang et al., 2009). Prolonged exposure to lead pollution affects the liver, kidneys and can cause infertility and mental retardation (Gunay, 2007; Ismael, 2012).

Numerous methods such as precipitation, water filtration processes using membranes, ion exchange and adsorbtion have been used to remove the lead (Gunay, 2007; Seliman, 2011). Some of theese methods proved to have disadvantages, such as high operation costs, incomplete removal of metals or the addition of chemical to the water to be treated (Seliman, 2011; Ishmael, 2012). Moreover, various materials have been used such as resins, carbon based materials, volcanic zeolitic tuffs or fly ash. Among all these, volcanic tuffs containing a particular mineral called zeolite, which functions as a "molecular sieve", has proven to be an effective material that offers very good results in wastewaters containing heavy metals, because of its unique property of exchanging ions with the liquid medium that interacts with (Ismael, 2012, Rusu et Rusu, 2009). They are abundant in the environment, quite easy to operate and have a low cost price.

The zeolites are microporous crystalline aluminosilicates with a tethraedrical structure, containing $\mathrm{Al}$ in the form of $\left[\mathrm{AlO}_{4}\right]^{5-}$ and $\mathrm{Si}$ in the form of $\left[\mathrm{SiO}_{4}\right]^{4-}$, where every metallic atom is surrounded by four oxygen atoms. They contain cations such as $\mathrm{Na}^{+}, \mathrm{K}^{+}, \mathrm{Ca}^{2+}$ şi $\mathrm{Mg}^{2+}$ in their pores and cavities, and water molecules as well (Payra, 2003; Shaheen et al., 2012). When the zeolite interacts with a solution containing heavy metals, the ion exchange process takes place. Therefore the cations contained in the zeolite pass in the solution, and the metal ions from the solution take their place in the zeolite structure. Figure 1 shows the chemical structure of the zeolite. 
Figure 1. Zeolite - chemical structure (a) (www.arixinternetteam.com), chemical structure schematically represented (b) (www.lenntech.pl), appearance (granular) (c) (www.buyagreenhouse.com)<smiles>O[Si](O)(O[AlH2])O[Al](O[SiH3])(O[SiH3])O[Si](O)(O)O[AlH2]</smiles>

a)

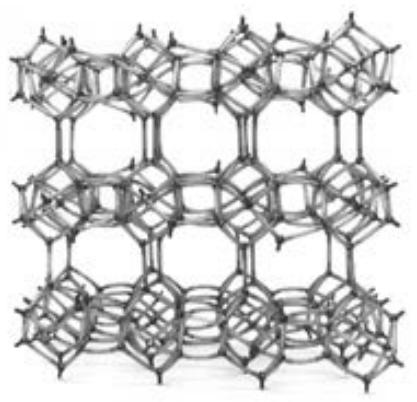

b)

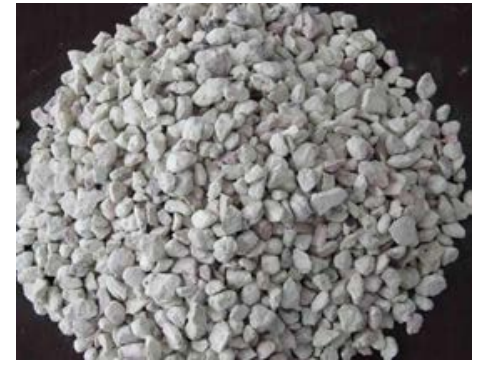

c)

The selectivity series of the heavy metals retained onto zeolites have been studied extensively in the literature for clinoptilolite - which is used in the present study. The most used is $\mathrm{Pb}>\mathrm{Cd}>\mathrm{Cs}>\mathrm{Cu}>$ $\mathrm{Co}>\mathrm{Cr}>\mathrm{Zn}>\mathrm{Ni}>\mathrm{Hg}$ (Baker et al., 2009; Wang, 2010; Shaheen et al., 2012). Most of the experiments in the literature were made at long interaction time frames, such as 3-4 hours (Gunay, 2007; Seliman, 2011), 24 hours (Baker, 2009) and even 48 hours (Keri et al., 2011), with a solution-zeolite ratio of 1:25 (Keri et al., 2011), 1:150 (Seliman, 2011) or even 1:400 (Gunay, 2007). These studies showed that a longer interaction time between the liquid media and the solid one is needed, if a reduced amount of zeolite is used, from economic reasons.

The present paper aims to study the retention of lead ions onto zeolite, in terms of its reaction rate, not in terms of filter material cost. This process was intended to be studied using the zeolite as a filter media in emergency situations scenario (environmental disaster, such a accidental discharge of heavy metals wastewaters in drinkable water supply sources), when the cost issue is not necessarily relevant. The interaction time between the zolite and the artificially poluted solution was a very short one, 1, 2.5 and 10 minute, therefore a larger amount of zeolite compared to the volume of the solution was needed, in order to obtain good results.

\section{Materials and methods}

\subsection{Materials}

The experiments were carried out using $60 \mathrm{~g}$ of clinoptilolite type of volcanic zeolitic tuff, chemically unmodified, $1.5-3 \mathrm{~mm}$ grain size and $40 \mathrm{ml}$ of artificially polluted lead acetate solution $\left(\mathrm{Pb}\left(\mathrm{CH}_{3} \mathrm{COO}\right)_{2}\right)$. The volcanic tuff $\left.\left(\mathrm{Na}_{3,35} \mathrm{~K}_{1.55} \mathrm{Ca}_{0.93} \mathrm{Ba}_{0.06} \mathrm{Sr}_{0.01}\right)\left(\mathrm{Al}_{6.9} \mathrm{Si}_{29.1} \mathrm{O}_{72}\right)\left(\mathrm{H}_{2} \mathrm{O}\right)_{4}\right)$ was exploited from Racoș area, Brașov County, Romania, by "Eleolit" LTD from Brașov. The mineralogical and chemical composition of the volcanic tuff is presented in Table 1. The $\mathrm{Pb}\left(\mathrm{CH}_{3} \mathrm{COO}_{2}\right)$ concentration is $6000 \mu \mathrm{g} / \mathrm{l}$, which is an aproximately 30 times higher value than the maximum allowed level for wastewater discharghing in a natural receptor regulated by the Romanian law (H.G.188/2002). The Pb measured concentration in this solutin is $3770 \mu \mathrm{g} / \mathrm{l}$.

Table 1. Mineralogical and chemical composition of volcanic zeolitic tuff (www.clinolit.ro)

\begin{tabular}{|c|c|c|c|c|c|}
\hline \multirow{8}{*}{$\begin{array}{l}\text { Mineralogical } \\
\text { composition }\end{array}$} & Zeolite & $83.3 \%$ & \multirow{8}{*}{$\begin{array}{c}\text { Chemical } \\
\text { composition }\end{array}$} & $\mathrm{SiO}_{2}$ & $68.75 \%$ \\
\hline & Plagioclaz & $6.6 \%$ & & $\mathrm{Al}_{2} \mathrm{O}_{3}$ & $11.35 \%$ \\
\hline & Volcanic glass & $6.3 \%$ & & $\mathrm{Fe}_{2} \mathrm{O}_{3}$ & $2.10 \%$ \\
\hline & Quartz & $2.6 \%$ & & $\mathrm{CaO}$ & $2.86 \%$ \\
\hline & Biotit & $1.2 \%$ & & $\mathrm{MgO}$ & $1.18 \%$ \\
\hline & \multirow{3}{*}{ Total: } & \multirow{3}{*}{$100.00 \%$} & & $\mathrm{Na}_{2} \mathrm{O}+\mathrm{K}_{2} \mathrm{O}$ & $3.99 \%$ \\
\hline & & & & $\begin{array}{l}\text { Loss through } \\
\text { calcination } \\
\text { (P.C.) }\end{array}$ & $9.77 \%$ \\
\hline & & & & Total: & $100.00 \%$ \\
\hline
\end{tabular}




\subsection{Research methods}

For the interaction of the zeolite with the liquid solution, a chromatographic column with frit and flow control valve was used, having a $25 \mathrm{~mm}$ diameter and $260 \mathrm{~mm}$ hight. The interaction time of the two media (liquid and solid) was established by setting the flow control valve of the column at 1, 2.5 and 10 minutes. The water temperature was $20^{\circ} \mathrm{C}$.

Three experiments were made for filtering the $\mathrm{Pb}\left(\mathrm{CH}_{3} \mathrm{COO}_{2}\right)$ solution, as follows: the cromatographic column was filled with $60 \mathrm{~g}$ of zeolite, then the standard solution was cast and eventually the flow control valve was set on 1 minute. There was no static interaction between the two media. The experiment was repeated then for 2.5 and 10 minutes.

The solution concentration, $\mathrm{pH}$ and electric conductivity were measured both before and after the filtration onto zeolite.

The preparation of the zeolite was made as follows :

a) by sieving in a $0.8 \mathrm{~mm}$ pore size sieve for the removal of the fine particles ;

b) washing with distilled water, 8 to 10 times ;

c) drying in an oven at $105^{\circ} \mathrm{C}$ for 6 hours.

\section{Equipment}

The measurements of the lead concentrations were made on an inductively coupled plasma mass spectrometer (SCIEX Perkin Elmer Elan DRC II, Toronto, Canada) at the Reasearch Institute for Analytical Instrumentation from Cluj-Napoca.

For the $\mathrm{pH}$ and electrical conductivity values a Mettler Toledo Seven Multi $\mathrm{pH}-\mathrm{meter}$ in the chemical research laboratory in the Department of Physics and Chemistry of the Technical University of Cluj-Napoca, was used.

Zeolite activation was made in a drying oven inthe same institution.

\section{Results and discussions}

The results obtained after filtering the solution, and the measured values of the $\mathrm{pH}$ and the electrical conductivity are shown in Table 2 .

Table 2. Experimental values of the solution concentration, $\mathrm{pH}$ and electrical conductivity, before and after the filtration on zeolite in a cromatographic column

\begin{tabular}{|c|c|c|c|c|}
\hline \multirow{2}{*}{$\begin{array}{l}\text { Experimental } \\
\text { values of the } \\
\mathrm{Pb}\left(\mathrm{CH}_{3} \mathrm{COO}\right)_{2} \\
\text { solution on: }\end{array}$} & \multirow{2}{*}{$\begin{array}{c}\text { Before the } \\
\text { filtration of } \\
\text { the } \\
\mathrm{Pb}\left(\mathrm{CH}_{3} \mathrm{COO}\right) 2 \\
\text { standard } \\
\text { solution }\end{array}$} & \multicolumn{3}{|c|}{$\begin{array}{l}\text { After the filtration of the } \mathrm{Pb}\left(\mathrm{CH}_{3} \mathrm{COO}\right) 2 \text { standard solution, on } \\
\text { different time frames } \\
\text { [minutes] }\end{array}$} \\
\hline & & 1 & 2.5 & 10 \\
\hline $\begin{array}{c}\mathrm{Pb}^{2+} \text { ions } \\
\text { concentration }[\mu \mathrm{g} / \mathrm{l}]\end{array}$ & 3770.00 & 15.00 & 9.30 & 6.80 \\
\hline pH & 5.60 & 7.39 & 7.49 & 7.51 \\
\hline $\begin{array}{c}\text { Electrical } \\
\text { conductivity } \\
{[\mu \mathrm{S} / \mathrm{cm}]}\end{array}$ & 21.60 & 99.70 & 113.90 & 231.00 \\
\hline
\end{tabular}

Thus, a significant reduction in the concentration of lead ions can be observed after the three experiments, with higher efficiency after 10 minutes, the longest interaction time set. The measured concentration after this time frame $(6.8 \mu \mathrm{g} / \mathrm{l})$ falls below the potability limit for lead $(10 \mu \mathrm{g} / \mathrm{l})$ as regulated by the Romanian law (Law 458/2002) (Figure 2). For the interaction time of 1 minute, the lead concentration value in the solution falls under $200 \mu \mathrm{g} / 1$ limit, which is the maximum allowed level for wastewater discharghing in a natural receptor regulated by the Romanian law (H.G.188/2002) 
Figure 2. Graphical representation of the lead concentration values in the $\mathrm{Pb}\left(\mathrm{CH}_{3} \mathrm{COO}\right)_{2}$ solution

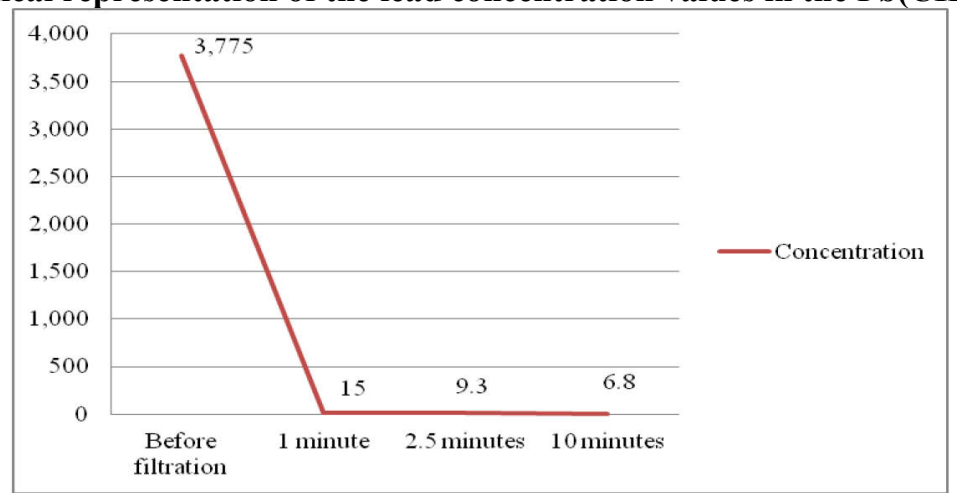

Figure 3. Graphical representation of the lead $\mathrm{pH}$ values in the $\mathrm{Pb}\left(\mathrm{CH}_{3} \mathrm{COO}\right)_{2}$ solution

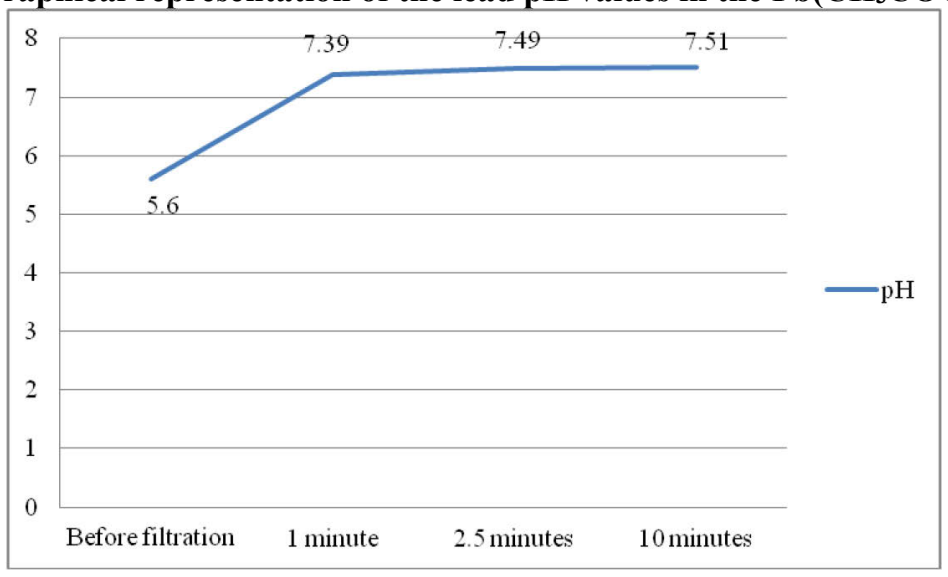

Furthermore, an increase in the $\mathrm{pH}$ value from 7.39 to 7.51 (Figure 3 ) is observed.

The electrical conductivity value increases from $99.7[\mu \mathrm{S} / \mathrm{cm}]$ to $231[\mu \mathrm{S} / \mathrm{cm}]$, which means an increase in the amount of dissolved salts in the solution due to the ion exchange process when interacting with zeolite (Figure 4).

Figure 4. Graphical representation of the lead electrical conductivity values in the $\mathrm{Pb}\left(\mathrm{CH}_{3} \mathrm{COO}\right)_{2}$ solution

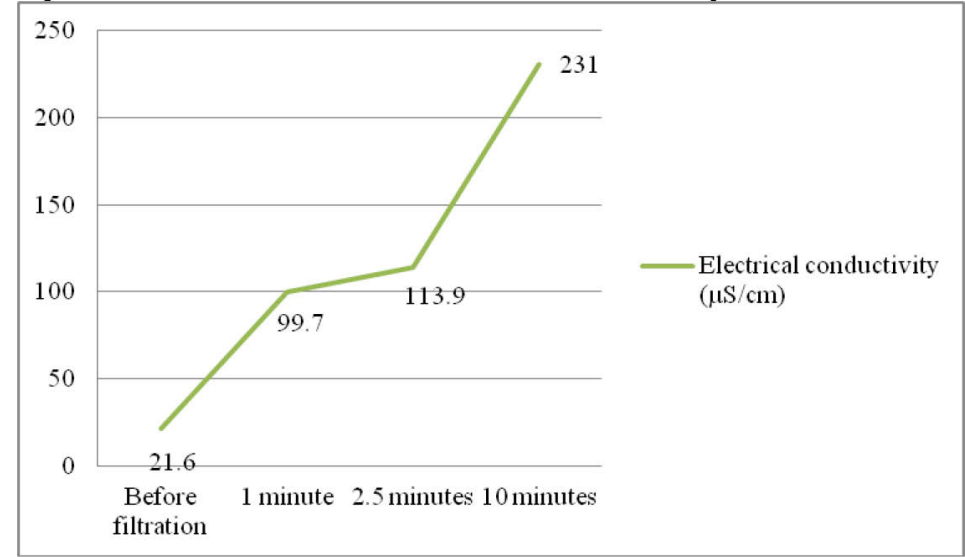

\section{Conclusions}

The experimental results in this study highlight the effective action of the zeolite on a lead containing solution, even under heavy pollution (approximately 30 times more than the maximum allowed level for wastewater discharghing in a natural receptor), at a reduced interaction time. But, in order to achieve these results, a larger amount of zeolite than the solution (to be treated) volume is needed. However, this should not be an impediment given the low cost of the zeolite. When it is critical to obtain a reduction of lead concentration in water in a short time (in case of environmental accidents on rivers or groundwater, or on any water supply sources), the costs involved are not a priority.

In order to obtain the results presented in this paper, a single passing of the lead polluted solution onto zeolite was needed to reduce its concentration. 
Both the minimum interaction time and the maximum interaction time resulted in obtaining values below certain limits regulated by the law: maximum allowed level for wastewater discharghing in a natural receptor for 1 minute interaction time and potability limit for 10 minutes interaction time.

The efficiency of the ion exchange process that takes place between the two media is confirmed by the determination of the three parameters : concentration, $\mathrm{pH}$ and electric conductivity, their values being obviously improved.

\section{Acknowledgements}

This paper was supported by the project "Improvement of the doctoral studies quality in engineering science for development of the knowledge based society-QDOC" contract no. POSDRU/107/1.5/S/78534, project co-funded by the European Social Fund through the Sectorial Operational Program Human Resources 2007-2013.

\section{References}

- Baker, H.M., Massadeh, A.M., Younes, H.A. (2009) Natural Jordanian zeolite: removal of heavy metal ions from water samples using column and batch methods, Environmental Monitoring and Assessment, 157, p.319-330.

- Gunay, A., Arslankaya, E., Tosun, I. (2011) Lead removal from aqueous solution bz natural and pretreated clinoptilolite: Adsorption equilibrium and kinetics, Journal of Hazardous Materials, 146, p.362-371.

- Ismael, I.S., Melegy, A., Kratochvil, T. (2012) Lead removal from aqueous solution by natural and pretreated zeolites, Geotechnical and Geological Engineering, 30, p.253-262.

- Payra, P., Dutta, P.K. (2003) Handbook of zeolite. Science and technology, Marcel Dekker Inc., New York.

- Rusu, T., Rusu, A., (2009). Purificarea Apelor Reziduale cu ajutorul Schimbătorilor de Ioni Naturali, ProEnvironment, 2, p.251-255. www.proenvironment.ro

- Shaheen, S.M., Derbalah, A.S., Moghanm F.S. (2012) Removal of heavy metals from aqueous solution by zeolite in competitive sorption system, International Journal of Environemtal Science and Development, 3 (4), p.362-367.

- Seliman, A.E., Borai, E.H. (2011) Utilization of natural chabazite and mordenite as a reactive barrier for immobilization of hazardous heavy metals, Environmental Science and Pollution Research, 18, p.1098-1107.

- Singh, A., Sharma, R.K., Agrawal, M., Marshall, F.M. (2010) Health risk assessment of heavy metals via dietary intake of foodstuffs from the wastewater irrigated site of a dry tropical area of India, Food and Chemical Toxicology, 48, p.611-619.

- Wang, S., Peng., Y. (2010) Natural zeolites as effective adsorbents in water and wastewater treatment, Chemical Engineering Journal, 156, p.11-24.

- Wang, Q., Zhao, H.H., Chen, J.W., Gu, K.D., Zhang, Y.Z., Zhu, Y.X., Zhou, Y.K., Ye, L.X. (2009) Adverse health effects of lead exposure on children and exploration to internal lead indicator, Science of the Total Environment, 407, p.5986-5992.

- Wang, X., Sato, T., Xing, B., Tao, S. (2005) Health risk of heavy metals to the general public in Tianjin, China via consumption of vegetables and fish, Science of the Total Environment, 350, p.28-37.

- Yi, Y., Yang, Z., Zhang, S. (2011) Ecological risk assessment of heavy metals in sediment and human health risk assessment of heavy metals in fishes in the middle and lower reaches of the Yangtze River basin, Environmental Pollution, 159, pp.2575-2585.

- www.arixinternetteam.com

- www.buyagreenhouse.com

- www.clinolit.ro

- www.lenntech.pl

- Government Decision no.188 from 20.03.2002 amended by Government Decision no.352 from 11.05.2005, publihed in Official Gazette no.398 from 11.05.2005.

- Law no.458/2002, amended by Law no.311/2004, published in Official Gazette no.552, Part I from 30.06.2004. 